\title{
Conversion of xylan by recyclable spores of Bacillus subtilis displaying thermophilic enzymes
}

\author{
Rosanna Mattossovich', Roberta lacono², Giuseppina Cangiano', Beatrice Cobucci-Ponzano², Rachele Isticato', \\ Marco Moracci ${ }^{1,2}$ and Ezio Ricca ${ }^{1 *}$ (D)
}

\begin{abstract}
Background: The Bacillus subtilis spore has long been used to display antigens and enzymes. Spore display can be accomplished by a recombinant and a non-recombinant approach, with the latter proved more efficient than the recombinant one. We used the non-recombinant approach to independently adsorb two thermophilic enzymes, GH10-XA, an endo-1,4- $\beta$-xylanase (EC 3.2.1.8) from Alicyclobacillus acidocaldarius, and GH3-XT, a $\beta$-xylosidase (EC 3.2.1.37) from Thermotoga thermarum. These enzymes catalyze, respectively, the endohydrolysis of (1-4)- $\beta$-D-xylosidic linkages of xylans and the hydrolysis of (1-4)- $\beta$-D-xylans to remove successive $D$-xylose residues from the non-reducing termini.
\end{abstract}

Results: We report that both purified enzymes were independently adsorbed on purified spores of B. subtilis. The adsorption was tight and both enzymes retained part of their specific activity. When spores displaying either GH10XA or GH3-XT were mixed together, xylan was hydrolysed more efficiently than by a mixture of the two free, not spore-adsorbed, enzymes. The high total activity of the spore-bound enzymes is most likely due to a stabilization of the enzymes that, upon adsorption on the spore, remained active at the reaction conditions for longer than the free enzymes. Spore-adsorbed enzymes, collected after the two-step reaction and incubated with fresh substrate, were still active and able to continue xylan degradation. The recycling of the mixed spore-bound enzymes allowed a strong increase of xylan degradation.

Conclusion: Our results indicate that the two-step degradation of xylans can be accomplished by mixing spores displaying either one of two required enzymes. The two-step process occurs more efficiently than with the two un-adsorbed, free enzymes and adsorbed spores can be reused for at least one other reaction round. The efficiency of the process, the reusability of the adsorbed enzymes, and the well documented robustness of spores of B. subtilis indicate the spore as a suitable platform to display enzymes for single as well as multi-step reactions.

\section{Background}

The display of biologically active molecules on the surface of microorganisms is an increasingly used strategy to address a variety of biotechnological issues [1,2]. For its remarkable stability, the bacterial endospore (spore) has also been considered as a display and delivery system [3]. Spores are mainly produced by Gram-positive

\footnotetext{
*Correspondence: ericca@unina.it

1 Department of Biology, Federico II University of Naples, Via Cinthia 4, 80126 Naples, MSA, Italy

Full list of author information is available at the end of the article
}

microorganisms of the Bacillus and Clostridium genera that share the ability to form a quiescent cellular type, the spore, in response to harsh environments. The spore is an extremely stable and resistant cell form that can survive in a dormant state for long periods, however, when the environmental conditions ameliorate, the spore germinates originating a vegetative cell able to grow and sporulate [4]. The ability of the spore to survive nonphysiological conditions is also due to its peculiar structure, characterized by a dehydrated cytoplasm containing a chromosome and surrounded by a series of protective 
structures: a peptidoglycan-like cortex and a multilayered, proteinaceous coat [4]. Some species have also an additional, outermost protective layer, the exosporium, formed also by proteins and glycoproteins [4].

Spores have been initially proposed for the development of mucosal vaccine delivery systems [5, 6]. More recently several enzymes have been successfully presented on the spore surface, suggesting the spore as an alternative platform to display biocatalysts with several potential advantages over other microbial systems based on the use of phages and bacterial or yeast cells [7-17]. Indeed, the remarkable and well documented stability and resistance of spores [4] ensures high stability to the display system [18].

Heterologous proteins can be displayed on the spore by a recombinant or by a non-recombinant approach [3, 4]. The recombinant method was originally developed to display a fragment of the tetanus toxin [19] and is based on the construction of gene fusions between the gene coding for a selected spore surface protein (carrier) and the heterologous DNA coding for the protein to be displayed. This method has the advantage that proteins are produced in the mother cell compartment of the sporulating cell and are assembled around the forming spore without the need to be translocated across a membrane, thus eliminating the size constrains of cell-based display systems [3]. The non-recombinant method has the advantages to be more efficient and to allow the display of proteins in their native form [20]. In addition, the nonrecombinant approach has been shown to stabilize the displayed protein against low $\mathrm{pH}$ conditions and high temperatures [7]. A recent study has shown that proteins displayed by the non-recombinant approach are not exposed on the spore surface but rather localized at the level of the inner coat [21]. This internal localization probably contributes to the protection of the heterologous protein without interfering with the biological activity of the displayed protein [21]. Both recombinant and non-recombinant systems have been initially developed using spores of Bacillus subtilis, the model organism for spore formers. However, other species have been also proposed and a recent study has shown that spores of $B$. megaterium, also for their large size, are particularly efficient in displaying high amounts of heterologous proteins [22].

We report the display on $B$. subtilis spores of two thermophilic enzymes, GH10-XA, an endo-1,4- $\beta$-xylanase (EC 3.2.1.8) from Alicyclobacillus acidocaldarius [23], and GH3-XT, a $\beta$-xylosidase (EC 3.2.1.37) from Thermotoga thermarum [23]. The two enzymes catalyze two successive steps of the degradation of xylans: the endohydrolysis of (1-4)- $\beta$-D-xylosidic linkages in xylans, GH10$\mathrm{XA}$, and the hydrolysis of (1-4)- $\beta$-D-xylans to remove successive $\mathrm{D}$-xylose residues from the non-reducing termini, GH3-XT. Therefore, the activity of GH10-XA produces more chain ends and increases the substrate for the action of GH3-XT [23]. Spore-displayed enzymes retained their enzymatic activities and when mixed together were able to perform the two-step release of xylose from xylan more efficiently than the two free enzymes. Spore-adsorbed enzymes were recycled after the first reaction and, incubated with fresh substrate, were able to continue xylan degradation.

\section{Results and discussion}

\section{Spore-adsorbed GH10-XA and GH3-XT are enzymatically active}

Two thermophilic enzymes, GH10-XA of $A$. acidocaldarius and GH3-XT of T. thermarum, were independently reacted with $1.0 \times 10^{10}$ purified spores of $B$. subtilis strain PY79 [24]. The adsorption reaction was performed by using $50 \mathrm{~g}$ of either one of the two purified proteins in $50 \mathrm{mM}$ sodium citrate at $\mathrm{pH} 4.0$, as previously described for other proteins [7, 20-22]. After the adsorption, spores were washed and collected by centrifugation. Spore surface proteins were extracted as described in the Methods section and analyzed by western blotting with anti-polyHis-Peroxidase antibody (Sigma), which recognizes the his-tagged C terminus of GH10-XA and of GH3-XT. Specific signals were observed with extracts of spores adsorbed with GH10-XA (Fig. 1a) or GH3-XT (Fig. 1b), therefore indicating that both enzymes were independently absorbed during the reaction and then released by the extraction treatment.

To evaluate the efficiency of adsorption, we followed a well-established procedure [20-22] and analyzed the amount of each enzyme left unbound, i.e., post-adsorbed spores were collected by centrifugation and the supernatant serially diluted and analyzed by dot blotting (Fig. 1c, d). The results of the densitometric analysis of the dot blotting (Tables 1 and 2) indicated that when $50 \mathrm{~g}$ of purified enzymes were reacted with $1.0 \times 10^{10}$ spores 30 and $50 \%$ of GH10-XA and GH3-XT, respectively, were adsorbed.

In order to assess whether the adsorbed enzymes retained their activity, after the adsorption reaction, spores were collected by centrifugation and assayed. Both enzymes were known to be active on 4-O-MethylD-glucurono-D-xylan (MGX) and 4-Nitrophenyl- $\beta$-Dxyloside [23], impairing the discrimination between the xylanase and xylosidase activities. Therefore, to distinguish between the two enzymatic activities, we used the chromogenic substrates 2 -Nitrophenyl- $\beta$-D-cellobioside and 4-Nitrophenyl- $\alpha$-L-arabinopyranoside, known to be specific for the GH10-XA xylanase and the GH3-XT xylosidase, respectively [23]. By this approach a specific 


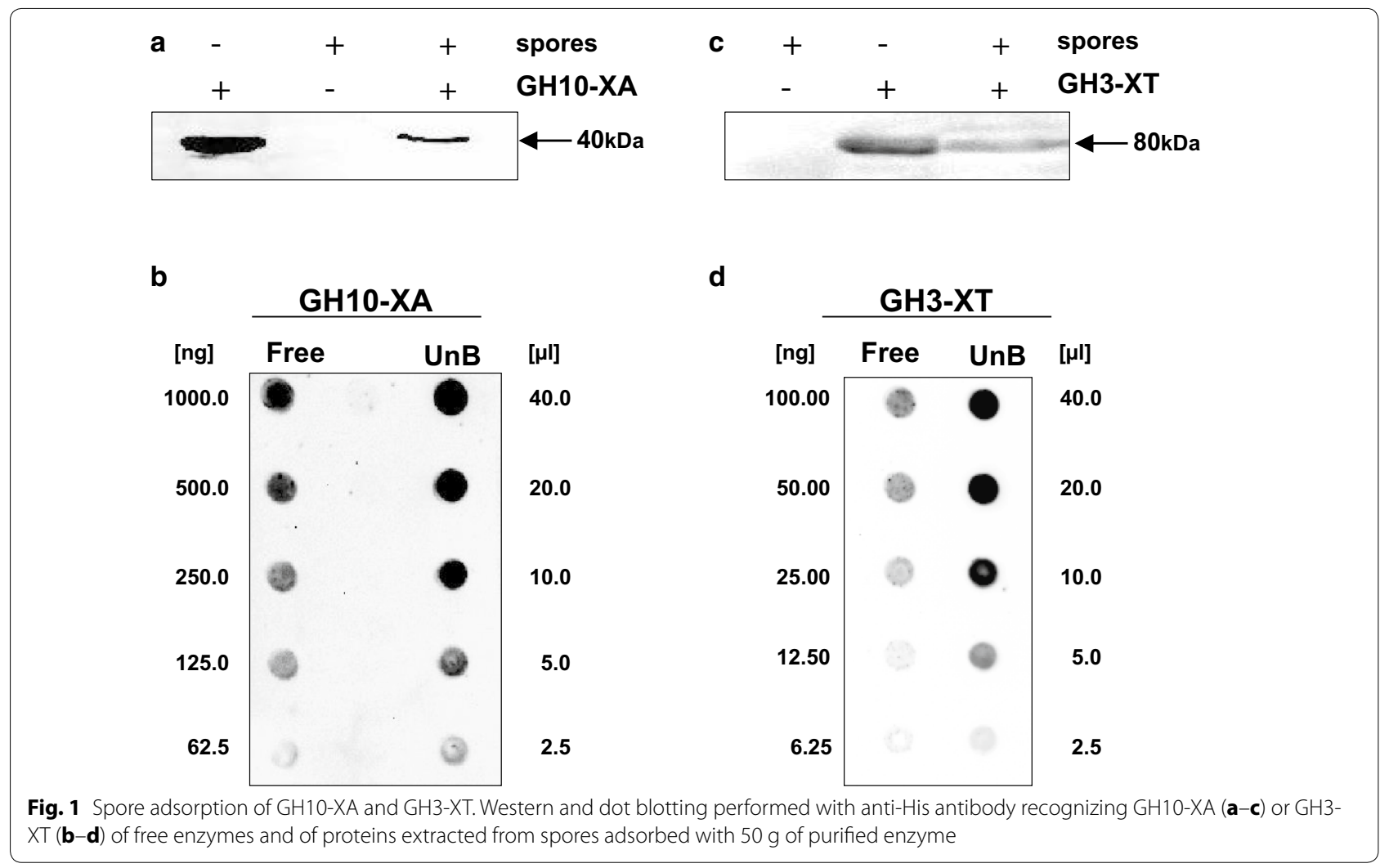

Table 1 Densitometric analysis of dot blot experiments with the supernatants of the adsorption reaction performed with $50 \mu \mathrm{g}$ xylanase (GH10-XA) and $1 \times 10^{10}$ spores

\begin{tabular}{|c|c|c|c|c|}
\hline Xylanase source & Amount of sample used & Density $\left(O D / \mathrm{mm}^{2}\right)^{a}$ & Amount of xylanase $(\mathrm{ng})^{\mathbf{b}}$ & Xylanase $\mu \mathrm{g}(\% \text { total })^{\mathbf{b}}$ \\
\hline \multirow[t]{5}{*}{ Purified xylanase (ng) } & 1000.0 & 690.77 & NA & NA \\
\hline & 500.0 & 450.37 & NA & NA \\
\hline & 250.0 & 204.87 & NA & NA \\
\hline & 125.0 & 176.36 & NA & NA \\
\hline & 62.5 & 114.49 & NA & NA \\
\hline \multirow[t]{3}{*}{ Unbound $(\mu \mathrm{l})$} & 10.0 & 1149.80 & 1855.10 & $34.08 \pm 2.36$ \\
\hline & 5.0 & 587.18 & 892.18 & $(68 \%)$ \\
\hline & 2.5 & 312.98 & 406.05 & \\
\hline
\end{tabular}

NA not applicable

a Density measured by optical density (OD) per square millimeter and obtained by ChemiDocXRS apparatus with Quantity-One software (Bio-Rad)

b Calculated from signals (density $\mathrm{OD} / \mathrm{mm}^{2}$ ) obtained with purified Xylanase

enzymatic activity was associated to spores adsorbed with either one of the two enzymes (white bars in Fig. 2). For GH10-XA and GH3-XT the total enzyme units adsorbed to spores was, respectively, 45 and $65 \%$ of those due to $50 \mu \mathrm{g}$ of free (not adsorbed to spores) enzyme (dark grey bars in Fig. 2). The spore-associated activities were not due to endogenous enzymes, since purified spores alone did not show any activity (light grey bars in Fig. 2). The adhesion was stable, since the same level of enzymatic activity was still associated to spores after two washes with phosphate buffer $\mathrm{pH} 4.0$ (black bars in Fig. 2).

For both enzymes, the efficiency of adsorption to the spore was slightly higher when estimated by comparing the respective activities (GH10-XA $=45 \%$ and GH3$\mathrm{XT}=65 \%$, Fig. 2) than by comparing the amount of adsorbed protein (GH10-XA $=30 \%$ and $\mathrm{GH} 3-\mathrm{XT}=50 \%$, Fig. 1b). This discrepancy is not surprising since an 
Table 2 Densitometric analysis of dot blot experiments with the supernatants of the adsorption reaction performed with $50 \mu \mathrm{g}$ xylosidase (GH3-XT) and $1 \times 10^{10}$ spores

\begin{tabular}{|c|c|c|c|c|}
\hline Xylosidase source & Amount of sample used & Density $\left(O D / \mathrm{mm}^{2}\right)^{\mathrm{a}}$ & Amount of xylosidase $(\mathrm{ng})^{\mathbf{b}}$ & Xylosidase $\mu \mathrm{g}(\% \text { total })^{\mathbf{b}}$ \\
\hline \multirow[t]{5}{*}{ Purified xylosidase (ng) } & 200.0 & $186,044.73$ & NA & NA \\
\hline & 100.0 & $96,438.20$ & NA & NA \\
\hline & 50.0 & $46,218.57$ & NA & NA \\
\hline & 25.0 & $18,201.76$ & NA & NA \\
\hline & 2.5 & $8,356.82$ & NA & NA \\
\hline Unbound $(\mu l)$ & 20.0 & $25,711.21$ & 254.38 & $23.6 \pm 0.9$ \\
\hline \multirow[t]{2}{*}{ Dilution 1:10 } & 10.0 & $11,745.32$ & 118.83 & $(47.2 \%)$ \\
\hline & 5.0 & 5387.66 & 57.12 & \\
\hline
\end{tabular}

NA not applicable

a Density measured by optical density (OD) per square millimeter and obtained by ChemiDocXRS apparatus with Quantity-One software (Bio-Rad)

b Calculated from signals (density $\mathrm{OD} / \mathrm{mm}^{2}$ ) obtained with purified Xylosidase

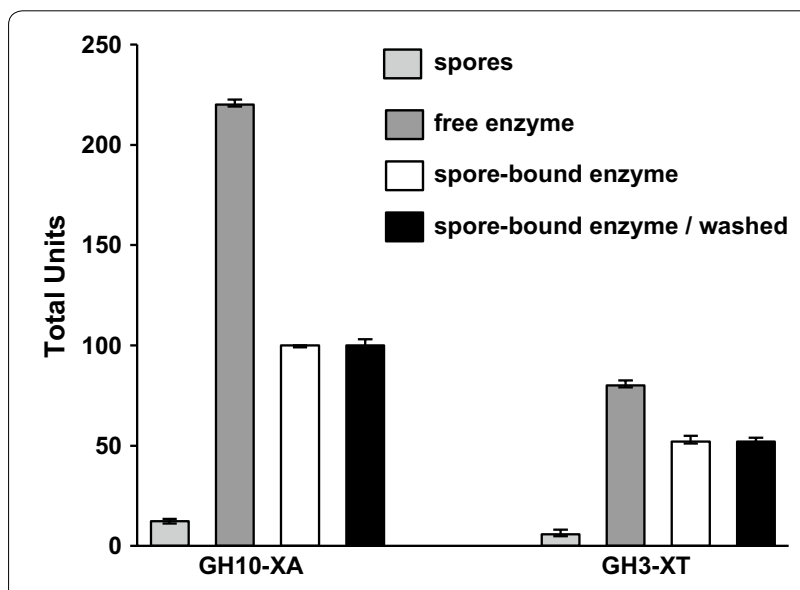

Fig. 2 Enzymatic activity of spore-adsorbed GH10-XA and GH3-XT. Specific activity obtained with free (dark grey bars) or spore-bound (white bars) enzymes. Enzymes were independently adsorbed to $1.0 \times 10^{10}$ spores. The activity of spores alone (light grey bars) and spore-bound enzymes after two washes (black bars) is reported

increased activity of a spore-adsorbed enzyme has been previously reported for the $\beta-\mathrm{Gal}$ of $A$. acidocaldaricus [7]. Based on the experiments of Figs. 1 and 2, we conclude that both enzymes were adsorbed to $B$. subtilis spores and that retained their activities upon binding to the spore.

\section{Spore adsorption alters the thermophilicity of GH10-XA and GH3-XT}

GH10-XA and GH3-XT are known to have $65{ }^{\circ} \mathrm{C}$ as optimal temperature and 6.5 as optimal $\mathrm{pH}$ of reaction [23]. In order to assess whether the enzyme properties were altered by the interaction with the spore, free and sporeadsorbed enzymes were assayed for xylanase (GH10-XA) or xylosidase (GH3-XT) activity at various temperature or $\mathrm{pH}$ conditions ("Methods"). Both spore-adsorbed enzymes showed a dependence to $\mathrm{pH}$ similar to that of the free enzymes (not shown). For GH10-XA the percentage of activity was higher for the spore-bound enzyme than for the free enzyme at temperatures lower $\left(55^{\circ} \mathrm{C}\right)$ and higher $\left(75^{\circ} \mathrm{C}\right)$ than the optimal (Fig. 3a). In the case of GH3-XT the percentage of activity due to the sporebound enzyme was slightly lower at $55^{\circ} \mathrm{C}$ and higher at $75^{\circ} \mathrm{C}$ than the free enzyme (Fig. 3b).

Results of Fig. 3 allow to conclude that the interaction with the spore did not have effects of the dependence of the enzymes on $\mathrm{pH}$ but altered the thermophilicity of both enzymes. While for free and spore-bound GH10XA the optimal temperature of reaction was not changed, for the spore-bound GH3-XT the activity was higher at $75^{\circ} \mathrm{C}$ than at $65^{\circ} \mathrm{C}$.

\section{Two-step conversion of xylan by free and spore-bound} enzymes

GH10-XA and GH3-XT catalyze two successive steps of the degradation of xylans: the endohydrolysis of (1-4)- $\beta$-D-xylosidic bonds and the hydrolysis of (1-4)- $\beta$-D-xylans to remove successive $D$-xylose residues from the non-reducing termini, respectively. In order to verify whether the two enzymes mixed together were able to perform the two sequential reactions, spores adsorbing either one of the two enzymes or the two free enzymes were mixed together. $1.0 \times 10^{10}$ spores were reacted with $50 \mathrm{~g}$ of GH10-XA or GH3-XT, collected by centrifugation, washed and resuspended in PBS ("Methods"). Different ratios (vol:vol) of spore-adsorbed GH10$\mathrm{XA}$ and spore-adsorbed GH3-XT were mixed together and reacted for $16 \mathrm{~h}$ with $\mathrm{MGX}$ as a substrate at $65^{\circ} \mathrm{C}$ and $\mathrm{pH}$ 6.5. In parallel, $50 \mu \mathrm{g}$ of free GH10-XA and GH3-XT were also mixed together in the same ratios (vol:vol) used for the spore-adsorbed enzymes. As shown in Fig. 4a, 

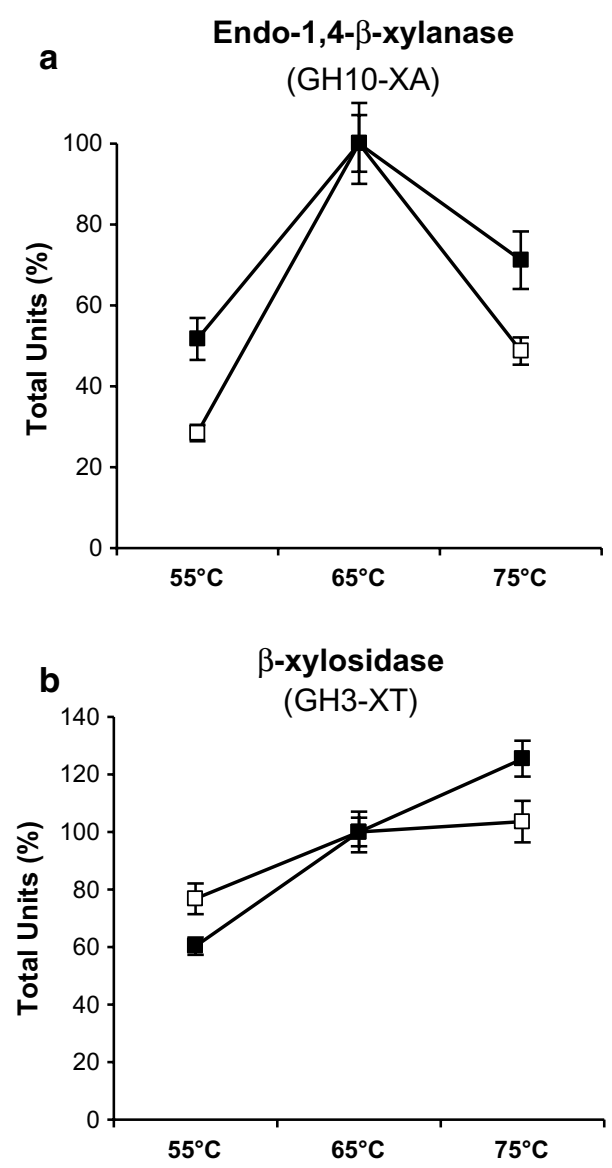

Fig. 3 Thermophily of spore-adsorbed GH10-XA and GH3-XT. Percentages of specific activity obtained with free (closed symbols) or spore-bound (open symbols) GH10-XA (a) and GH3-XT (b) at various temperatures. In both panels it was considered as $100 \%$ the activity measured at the optimal temperature of the free enzymes $\left(65^{\circ} \mathrm{C}\right)$ when the ratio xylanase:xylosidase was 1:1 (vol:vol) the free and spore-bound enzymes were able to produce similar amounts of reducing termini. However, when different ratios of xylanase:xylosidase were used, an increased production of reducing termini was observed with the 2:1 (vol:vol) but not with the 1:2 (vol:vol) ratio (Fig. 4a). This increase was observed only with the spore-bound enzyme, suggesting that the amount of spore-bound GH10-XA was limiting in the two-step conversion of MGX. A further increase of the amount of GH10-XA in the mixture, 3:1 (vol:vol) ratio of xylanase:xylosidase, only caused a minimal increase in the production of reducing termini, suggesting the 2:1 (vol:vol) ratio as the most convenient condition for this two-step reaction (Fig. 4a). Free GH10-XA and GH3-XT have been previously reported to independently produce low amounts reducing ends using MGX as a substrate $(8.6 \pm 0.4$ and $2.1 \pm 0.1 \mathrm{mM}$, respectively) [23]. Spore-bound GH10-XA or GH3-XT were assayed independently with MGX as substrate and showed a production of $8.2 \pm 1.41$ and $1.0 \pm 0.75 \mathrm{mM}$ of reducing ends, respectively, that correspond to a basal level activity with respect to those observed with the mixture of free or spore-bound enzymes (Fig. 4a).

Results of Tables 1 and 2 and of Fig. 2 showed that the efficiency of spore adsorption was higher for GH3-XT than for GH10-XA. In particular, the experiments of Fig. 2 indicated that 45 and $65 \%$ of the activity due to $50 \mathrm{~g}$ of GH10-XA or GH3-XT, respectively, were adsorbed to $1.0 \times 10^{10}$ spores. Therefore, mixing spore-adsorbed GH10-XA and spore-adsorbed GH3-XT in the 2:1 (vol:vol) ratio (Fig. 4a), led to the observed production of reducing termini by 45 and $32.5 \mathrm{~g}$ of GH10-XA and GH3$\mathrm{XT}$, respectively.
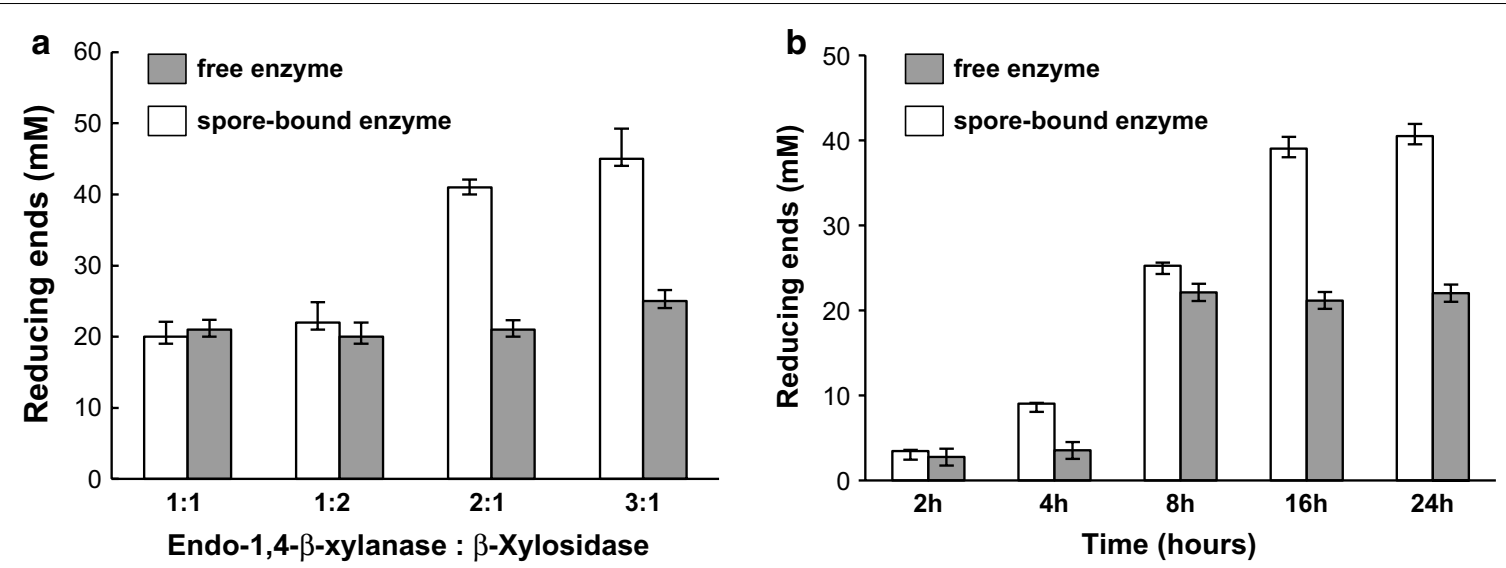

Fig. 4 Set up of the two-step reaction. Production of reducing termini obtained by mixing free (grey bars) or spore-bound (white bars) enzymes in different relative ratios (vol:vol) (a) or after different incubation times (b). Reactions for the experiments of panel A were carried out for $16 \mathrm{~h}$. Reactions for the experiments of panel B were performed using a 2:1 (vol:vol) ratio of GH10-XA:GH3-XT 
Degradation of xylans was assayed after $16 \mathrm{~h}$ (Fig. 4a). To identify the most appropriate conditions for the twostep reaction, we followed the degradation of MGX with free and spore-bound enzymes mixed together in the 2:1 (vol:vol) ratio for various incubation times at $65{ }^{\circ} \mathrm{C}$. At each time point, aliquots of the reactions were collected and used to assay the production of reducing ends ("Methods"). As shown in Fig. 4b, a time-dependent increase of the production of reducing ends was observed with a maximum reached after $8 \mathrm{~h}$ by the free enzymes and after $16 \mathrm{~h}$ by the spore-bound enzymes (Fig. 4b). Consistently with the experiment of Fig. 4a, higher amounts of reducing ends were obtained with spore-bound than with free enzymes.

Since the reactions with both free and spore-bound enzymes were performed with the same concentration of substrate, we infer that the reaction of the free enzymes did not continue after $8 \mathrm{~h}$ because at least one of the two enzymes was no longer active. This, in turn, suggests that at least one of the adsorbed enzymes was stabilized by the interaction with the spore.

The efficiency of MGX hydrolysis by spore-bound and unbound GH10-XA and GH3-XT enzymes, respectively, was compared in identical conditions (Table 3). Interestingly, the degree of synergy, defined as the ratio of xylose equivalents produced by the two enzymes to the sum of the xylose equivalents released by each individual enzyme [25], was significantly higher in the reaction catalyzed by the spore-bound enzymes, further confirming the utility of this method. In addition, the degree of synergy of 2.71 after $8 \mathrm{~h}$ of reaction time is remarkably high, considering that values lower than 2 after $12 \mathrm{~h}$ of reaction time have been previously reported in other systems based on free enzymes [25].

\section{Spore-bound enzymes are stable and reusable}

The hypothesis that the interaction with the spore stabilized at least one of the enzymes induced us to verify whether the spore-adsorbed enzymes could be collected and recycled. To this aim the two-step reaction was performed for $16 \mathrm{~h}$ at $65{ }^{\circ} \mathrm{C}$ with spore-bound enzymes mixed together in the 2:1 (vol:vol) ratio. Then, one-third of the reaction mixture was stored and the remaining part centrifuged to collect the spores. The pellet was split in two parts and each part reacted again for $16 \mathrm{~h}$ at $65^{\circ} \mathrm{C}$ with or without the addition of fresh substrate (MGX). After the second reaction round the three aliquots were used to assay the production of reducing ends. As shown in Fig. 5a, amounts of reducing ends similar to those obtained in the experiments of Fig. 4 were obtained after the first reaction round. With the second reaction, additional amounts of reducing termini were produced only if fresh substrate was added to the reaction (Fig. 5a). Absence of reducing ends when no fresh substrate was added, clearly indicated that the reducing ends detected upon the addition of fresh xylan were new degradation products due to the still active spore-bound enzymes.

The conclusion that the spore-bound enzymes are still active after the first reaction, raised the question of why the production of reducing ends did not continue after $16 \mathrm{~h}$ and no further degradation was observed after $24 \mathrm{~h}$ in the experiment of Fig. 4b with spore-bound enzymes. One possible explanation is that the substrate was limiting the reaction and no further degradation occurred because there was no xylan available. To verify this possibility the two-step reaction was performed with free and sporebound enzymes mixed together in the 2:1 (vol:vol) ratio. After $16 \mathrm{~h}$ at $65^{\circ} \mathrm{C}$ half of the reaction mixture was stored while the other half was used to continue the reaction with fresh substrate for other $16 \mathrm{~h}$ at $65{ }^{\circ} \mathrm{C}$. After the second reaction round the two aliquots were used to assay the production of reducing ends. No increase in the production of reducing ends was observed with the free or spore-bound enzymes (Fig. 5b). Based on Fig. 4b, the result Fig. 5b with free enzymes was expected and confirmed that at least of the enzymes is no longer active. Results with spore-bound enzymes indicated that the reaction was not limited by the availability of the substrate.

Since the spore-bound enzymes were still active (Fig. 5a) and the substrate was not limiting the reaction (Fig. 5b), we suggest that the two-step reaction did not continue after $16 \mathrm{~h}$ and no more reducing ends were

Table 3 Comparison of the yields of MGX hydrolysis by the combined GH10-XA and GH3-XT enzymes

\begin{tabular}{|c|c|c|c|c|c|c|c|c|}
\hline \multirow[t]{2}{*}{ Time } & \multicolumn{4}{|c|}{ Unbound (reducing sugar yields mM) } & \multicolumn{4}{|c|}{ Spore-bound (reducing sugar yields $\mathrm{mM}$ ) } \\
\hline & GH10-XA & GH3-XT & $\begin{array}{l}\text { GH10-XA + GH3- } \\
\text { XT }\end{array}$ & $\begin{array}{l}\text { Degree } \\
\text { of synergy }^{a}\end{array}$ & GH10-XA & GH3-XT & $\mathrm{GH} 10-\mathrm{XA}+\mathrm{GH} 3-\mathrm{XT}$ & $\begin{array}{l}\text { Degree of } \\
\text { synergy }^{\text {a }}\end{array}$ \\
\hline $2 \mathrm{~h}$ & $1.49 \pm 0.04$ & ND & $2.73 \pm 0.26$ & 1.83 & $3.26 \pm 0.18$ & ND & $3.42 \pm 0.14$ & 1.05 \\
\hline $4 \mathrm{~h}$ & $3.98 \pm 0.16$ & ND & $3.51 \pm 0.18$ & 0.88 & $6.09 \pm 0.08$ & $0.11 \pm 0.01$ & $9.03 \pm 0.06$ & 1.46 \\
\hline $8 \mathrm{~h}$ & $14.65 \pm 0.91$ & $1.46 \pm 0.64$ & $22.10 \pm 0.71$ & 1.37 & $11.00 \pm 1.41$ & $0.52 \pm 0.06$ & $25.25 \pm 0.35$ & 2.71 \\
\hline $16 \mathrm{~h}$ & $15.65 \pm 0.50$ & $1.90 \pm 0.14$ & $21.15 \pm 1.62$ & 1.21 & $17.00 \pm 1,41$ & $1.85 \pm 0.21$ & $39.00 \pm 1.41$ & 2.07 \\
\hline
\end{tabular}

${ }^{a}$ Ratio of xylose equivalents from enzyme reactions to the sum of the xylose equivalents released by the individual enzymes [25] 

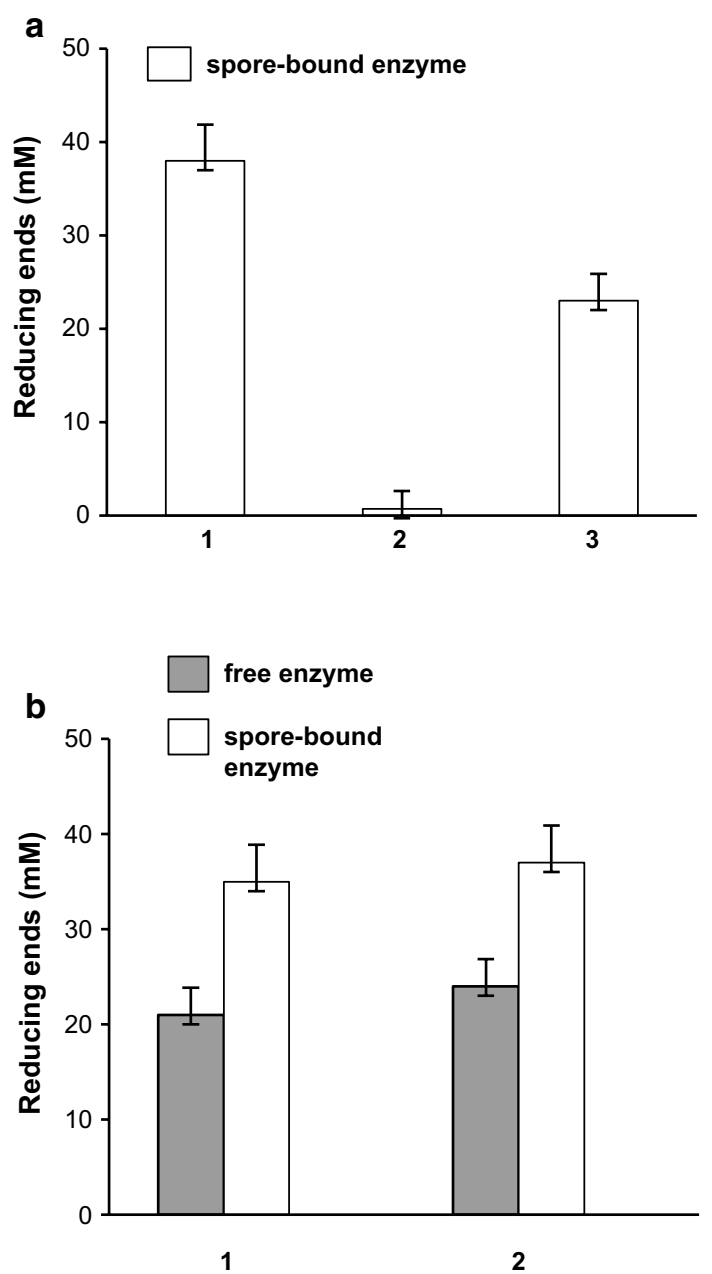

Fig. 5 Recycled reaction. a Activity of spore-bound enzymes after the first reaction (1) and after the second reaction with spores collected by centrifugation and re-incubated without (2) or with (3) the addition of fresh substrate. $\mathbf{b}$ Activity of free (grey bars) or sporebound (white bars) enzymes after the first reaction (1) and after the second reaction with fresh substrate (2). In both panels, each reaction round was performed for $16 \mathrm{~h}$ at $65^{\circ} \mathrm{C}$

produced in the experiment of Fig. $4 \mathrm{~b}$ after $16 \mathrm{~h}$ because of the accumulation of the reaction products. When these products were removed by centrifugation the still active enzymes associated to the spore continued the degradation and more reducing ends were produced (Fig. 5a).

\section{Conclusions}

We report that two thermophilic enzymes can be adsorbed on $B$. subtilis spores retaining their activity, that a two-step reaction can be catalyzed by mixing together spores displaying either one of the two enzymes, that the spore-bound enzymes hydrolyze their substrate more efficiently than the unbound ones, and that the mixture of spore-bound enzymes can be recycled.
A series of reports have previously shown that a variety of different enzymes can be displayed in an active form on bacterial spores [7-17]. Here it is reported the display of two enzymes catalyzing two sequential reactions, with the product of the reaction catalyzed by one enzyme (GH10-XA) that is the substrate of the second enzyme (GH3-XT). In particular, GH10-XA is an endo-1,4- $\beta$-xylanase of $A$. acidocaldarius and catalyzes the endohydrolysis of (1-4)- $\beta$-D-xylosidic linkages in xylans while GH3-XT is a $\beta$-xylosidase of $T$. thermarum and catalyzes the exohydrolysis of (1-4)- $\beta$-D-xylans to remove successive $\mathrm{D}$-xylose residues from the nonreducing termini [23]. Main novelty of this report is the observation that the mixture of spores adsorbing GH10$\mathrm{XA}$ and spore adsorbing GH3-XT was able to efficiently catalyze the two-step degradation of MGX to release xylose. A similar synergistic effect has been recently reported with a xylanase and a $\beta$-xylosidase from Geobacillus thermodenitrificans acting on different types of xylan, but MGX [25].

The free enzymes were also able to perform the twostep reaction but the efficiency of the process was double with the mixture of spore-bound enzymes (Fig. 4a). The reason for the high efficiency of the reaction with spore-bound enzymes is most likely the stabilization of at least one of the enzymes upon adsorption on the spore. Indeed, it has been previously shown that the interaction with the spore has a positive effect on enzyme stability [7] and here it is reported that while the mixture of free enzymes was no longer active after $8 \mathrm{~h}$ at $65{ }^{\circ} \mathrm{C}$, the spore-bound enzymes were able to catalyze xylose removal for at least $16 \mathrm{~h}$ at $65{ }^{\circ} \mathrm{C}$ (Fig. 4b). After that only when the accumulated end-product was removed, MGX degradation continued (Fig. 5b), indicating that the spore-bound enzymes were still active after $16 \mathrm{~h}$ of incubation.

When spore-bound enzymes were collected and reincubated with fresh substrate (MGX) the two-step reaction continued and more reducing termini were produced (Fig. 5a). This is an additional important new finding of this report. Spore-adsorbed enzymes are stable and can be collected and reused allowing an overall increase in the total amount of xylose produced.

This report, therefore, highlights new advantages of using spores of $B$. subtilis to display enzymes: the stabilization of the enzymes, the possibility of performing two-step reactions and the possibility to collect and recycle the used enzymes. These properties, together with the well documented robustness of spores of $B$. subtilis, propose the spore as a suitable platform for biocatalytic processes. 


\section{Methods}

\section{Bacterial strains and spore purification}

The B. subtilis strain used in this study was PY79 [24]. Sporulation was induced by the exhaustion method [26]. After $30 \mathrm{~h}$ of growth in Difco Sporulation (DS) medium at $37{ }^{\circ} \mathrm{C}$ with vigorous shaking spores were collected, washed three times with distilled water and purified by gastrografin gradient as described by Nicholson and Setlow [26]. Spore counts were determined by serial dilution and plate-counting.

\section{Purification of GH10-XA and GH3-XT}

The gene coding for GH10-XA was cloned, expressed and purified as previously described [23] with the following modifications. Plasmid pET101/D-TOPOAaci_2328, carrying the GH10-XA gene under the control of an isopropyl-1-1 thio- $\beta$-D-galactopyranoside (IPTG) inducible T7 RNA polymerase promoter and with $6 \times$ His tag fused to the $C$ terminus of the encoded protein, was expressed in Escherichia coli cells, strain BL21 Star (DE3). Transformed cells were grown at $37^{\circ} \mathrm{C}$ in 21 of Luria-Bertani (LB) broth supplemented with ampicillin $\left(50 \mu \mathrm{g} \mathrm{ml}^{-1}\right)$. Gene expression was induced by the addition of $0.1 \mathrm{mM}$ IPTG when the culture reached an $\mathrm{A}_{600}$ of 1.0. Growth was allowed to proceed for $16 \mathrm{~h}$, the resulting cell-pellet was resuspended in $50 \mathrm{mM}$ sodium phosphate buffer, $\mathrm{pH} 8.0,300 \mathrm{Mm} \mathrm{NaCl}$ and 1\% TRITON-X100 and cells were lysed by French cell pressure treatment. The free cellular extract (FCE) was loaded on a His Trap FF crude column (GE-Healthcare) [23].

The gene coding for GH3-XT was cloned, expressed and purified as previously described [27] with the following modifications. Plasmid pET-20b-GH3-XT, carrying the GH3-XT gene under the control of an IPTG-inducible T7 RNA polymerase promoter and with $6 \times$ His tag fused to the $\mathrm{C}$ terminus of the encoded protein, was transformed into E. coli BL21 (DE3). Gene expression was induced by adding IPTG to final concentration of $0.5 \mathrm{mM}$ at $\mathrm{OD}_{600}$ approximately 0.8 and incubated further ay $37^{\circ} \mathrm{C}$ for about $16 \mathrm{~h}$. The recombinant cells were harvested by centrifugation and resuspended in $5 \mathrm{mM}$ imidazole, $0.5 \mathrm{mM} \mathrm{NaCl}$ and $20 \mathrm{mM}$ Tris-Hcl buffer $(\mathrm{pH}$ 7.9). The cell extracts after sonication were heat treated and then cooled in an ice bath, and centrifuged. The supernatants were loaded onto a His Trap FF Crude (GE-Healthcare).

\section{Spore adsorption and enzyme assays}

$50 \mu \mathrm{g}$ of each purified enzyme were added to a suspension of spores $\left(1.0 \times 10^{10}\right)$ in $0.15 \mathrm{M} \mathrm{PBS} \mathrm{pH} 4.0$ at $25^{\circ} \mathrm{C}$ in a final volume of $200 \mu \mathrm{l}$. After $1 \mathrm{~h}$ of incubation, the binding mixture was centrifuged (10 $\mathrm{min}$ at $13,000 \mathrm{~g}$ ) to fractionate enzyme-bound spores (pellet) from unbound enzyme (supernatant).

The pellet fraction and $50 \mu \mathrm{g}$ of each purified enzyme were resuspended in $200 \mu \mathrm{l}$ of $1 \times$ PBS. For the xylanase and $\beta$-xylosidase assays, $20 \mu \mathrm{l}$ of pellet fraction or free enzyme were diluted to a final volume of $200 \mu \mathrm{l}$ in reaction buffer $(50 \mathrm{mM}$ Sodium phosphate buffer at $\mathrm{pH} 6.5$; 2 -Nitrophenyl- $\beta$-D-cellobioside $8 \mathrm{mM}$ for the xylanase assay and $50 \mathrm{mM}$ Sodium phosphate buffer at $\mathrm{pH}$ 6.5, 4-Nitrophenyl- $\alpha$-L-arabinopyranoside $1 \mathrm{mM}$ for $\beta$-xylosidase the assay) and incubated at $65{ }^{\circ} \mathrm{C}$ for $1 \mathrm{~min}$. The reaction was stopped by adding $800 \mu \mathrm{l}$ of $1 \mathrm{M}$ $\mathrm{Na}_{2} \mathrm{CO}_{3}$. Samples containing spores were centrifuged prior to measurement of optical density at $420 \mathrm{~nm}$. We expressed results of enzymatic assays in total units, where 1 unit is defined as an amount of xylanase or $\beta$-xylosidase able to hydrolyse $1 \mu \mathrm{mol}$ of substrate in $1 \mathrm{~min}$ at standard condition.

Mixtures of spores adsorbing GH10-XA or GH3-XT were incubated in $50 \mathrm{mM}$ sodium phosphate buffer $\mathrm{pH}$ 6.5 , at $65^{\circ} \mathrm{C}$ in the presence of 4-O-Methyl-D-glucuronoD-xylan (MGX) (5 $\mathrm{mg} \mathrm{ml}^{-1}$ ) for various times in the final volume of $0.1 \mathrm{ml}$. The relative activity was measured according to the Somogyi-Nelson method [28, 29], estimating the amount of reducing sugars released after $16 \mathrm{~h}$.

For the recycling test, the first reaction was performed for $16 \mathrm{~h}$ at $65{ }^{\circ} \mathrm{C}$ with spore-bound enzymes mixed together in the 2:1 (vol:vol) ratio. After that, one-third of the reaction mixture was stored at $4{ }^{\circ} \mathrm{C}$ and the remaining part centrifuged $(15 \mathrm{~min}$ at $13,000 \mathrm{~g})$ to collect the spores. The pellet was resuspended in $50 \mathrm{mM}$ sodium phosphate buffer and split in two parts. Each part was reacted again for $16 \mathrm{~h}$ at $65^{\circ} \mathrm{C}$ in $50 \mathrm{mM}$ sodium phosphate buffer $\mathrm{pH}$ 6.5 with or without the addition of fresh substrate (MGX $5 \mathrm{mg} \mathrm{ml}^{-1}$ ). After the second reaction round the three aliquots were assayed following the Somogyi-Nelson method [28, 29], as above.

\section{Western and dot-blot analysis}

Spore-adsorbed enzymes were resuspended in $60 \mu \mathrm{l}$ of spore coat extraction buffer, incubated at $70{ }^{\circ} \mathrm{C}$ for $1 \mathrm{~h}$ to solubilize spore coat proteins and loaded into a $12 \%$ SDSPAGE gel. The proteins were then electro-transferred to nitrocellulose filters (Amersham Pharmacia Biotech) and analysed by Western blot analysis using monoclonal enzyme-recognizing anti-His antibody (Sigma) [21]. A quantitative determination of the amounts of enzymes was obtained by dot blot experiments and densitometric analysis as previously reported [20]. Dot blot and relative densitometric analyses were performed three times.

\section{Authors' contributions}

RM: performed most of the experiments. RI contributed to enzyme purification and enzymatic assays. GC contributed to experiment design and spore 
analysis. BCP contributed to experiment design and enzyme analysis; RI contributed to the western- and dot-blotting analysis and manuscript writing. MM contributed to experiment design, discussion and manuscript writing. ER contributed discussions and suggestions during the work and wrote most of the manuscript. All authors read and approved the final manuscript.

\section{Author details}

${ }^{1}$ Department of Biology, Federico II University of Naples, Via Cinthia 4, 80126 Naples, MSA, Italy. ${ }^{2}$ Institute of Biosciences and BioResources, CNR, Naples, Italy

\section{Acknowledgements}

Not applicable.

\section{Competing interests}

The authors declare that they have no competing interests.

\section{Availability of data and materials}

All data on which the conclusions of this manuscript rely are presented in the manuscript.

\section{Consent for publication \\ Not applicable.}

Ethics approval and consent to participate Not applicable.

\section{Funding}

This work was supported by the Italian Ministry of Education (MIUR), project PON-Biopolis to ER and MM.

\section{Publisher's Note}

Springer Nature remains neutral with regard to jurisdictional claims in published maps and institutional affiliations.

Received: 1 August 2017 Accepted: 21 November 2017

Published online: 28 November 2017

\section{References}

1. Wu CH, Mulchandani A, Chen W. Versatile microbial surface-display for enviromental remediation and biofuels production. Trends Microbiol. 2008;16:181-8.

2. Lee SY, Choi JH, Xu Z. Microbial cell-surface display. Trends Biotechnol. 2003;21:45-52.

3. Isticato R, Ricca E. Spore surface display. Microbiol Spectr. 2014;2:351-66.

4. Henriques AO, Moran CP Jr. Structure, assembly and function of the spore surface layers. Annu Rev Microbiol. 2007;61:555-88.

5. Cutting SM, Hong HA, Baccigalupi L, Ricca E. Oral vaccine delivery by recombinant spore probiotics. Int Rev Immunol. 2009:28:487-505.

6. Ricca E, Baccigalupi L, Cangiano G, De Felice M, Isticato R. Mucosal vaccine delivery by non-recombinant spores of Bacillus subtilis. Microb Cell Fact. 2014;13:115

7. Sirec T, Strazzulli A, Isticato R, De Felice M, Moracci M, Ricca E. Adsorption of beta-galactosidase of Alicyclobacillus acidocaldarius on wild type and mutants spores of Bacillus subtilis. Microb Cell Fact. 2012;11:100.

8. Chen H, Zhang T, Jia J, Vastermark A, Tian R, Ni Z, Chen Z, Chen K, Yang S. Expression and display of a novel thermostable esterase from Clostridium thermocellum on the surface of Bacillus subtilis using the CotB anchor protein. J Ind Microbiol Biotechnol. 2015;42:1439-48.

9. Chen H, Tian R, Ni Z, Zhang Q, Zhang T, Chen Z, Chen K, Yang S. Surface display of the thermophilic lipase Tm1350 on the spore of Bacillus subtilis by the CotB anchor protein. Extremophiles. 2015;19:799-808.
10. Chen H, Zhang T, Sun T, Ni Z, Le Y, Tian R, Chen Z, Zhang C. Clostridium thermocellum nitrilase expression and surface display on Bacillus subtilis spores. J Microbiol Biotechnol. 2015;25:381-7.

11. Wang $H$, Yang R, Hua X, Zhang W, Zhao W. An approach for lactulose production using the CotX-mediated spore-displayed $\beta$-galactosidase as a biocatalyst. J Microbiol Biotechnol. 2016;26:1267-77.

12. Gao F, Ding $H$, Xu X, Zhao Y. A self-sufficient system for removal of synthetic dye by coupling of spore-displayed triphenylmethane reductase and glucose 1-dehydrogenase. Environ Sci Pollut Res. 2016;23:21319-26.

13. Hosseini-Abari A, Kim BG, Lee SH, Emtiazi G, Kim W, Kim JH. Surface display of bacterial tyrosinase on spores of Bacillus subtilis using CotE as an anchor protein. J Basic Micobiol. 2016;56:1331-7.

14. Chen H, Chen Z, Wu B, Ullah J, Zhang T, Jia J, Wang H, Tan T. Influences of various peptide linkers on the Thermotoga maritima MSB8 nitrilase displayed on the spore surface of Bacillus subtilis. J Mol Microbiol Biotechnol. 2017:27:64-71

15. He W, Jiang B, Mu W, Zhang T. Production of D-Allulose with D-Psicose 3-epimerase expressed and displayed on the surface of Bacillus subtilis spores. J Agric Food Chem. 2016;64:7201-7.

16. Chen L, Mulchandani A, Ge X. Spore-displayed enzyme cascade with tunable stoichiometry. Biotechnol Prog. 2017;33:2.

17. Sheng S, Jia H, Topiol S, Farinas ET. Engineering CotA laccase for acidic pH stability using Bacillus subtilis spore display. J Microbiol Biotechnol. 2017:27:507-13.

18. Knecht LD, Pasini P, Daunert S. Bacterial spores as platforms for bioanalytical and biomedical applications. Anal Bioanal Chem. 2011;400:977-89.

19. Isticato R, Cangiano G, Tran HT, Ciabattini A, Medaglini D, Oggioni MR, De Felice M, Pozzi G, Ricca E. Surface display of recombinant proteins on Bacillus subtilis spores. J Bacteriol. 2001:183:6294-301.

20. Isticato R, Sirec T, Treppiccione L, Maurano F, De Felice M, Rossi M, Ricca E. Non-recombinant display of the B subunit of the heat labile toxin of Escherichia coli on wild type and mutant spores of Bacillus subtilis. Microb Cell Fact. 2013;12:98.

21. Donadio G, Lanzilli M, Sirec T, Ricca E, Isticato R. Localization of a red fluorescence protein adsorbed on wild type and mutant spores of Bacillus subtilis. Microb Cell Fact. 2016;15:153.

22. Lanzilli M, Donadio G, Addevico R, Saggese A, Cangiano A, Baccigalupi $L$, Christie G, Ricca E, Isticato R. The exosporium of Bacillus megaterium QM B1551 is permeable to the red fluorescence protein of the coral Discosoma sp. Front Microbiol. 2016:7:1752.

23. Cobucci-Ponzano B, Strazzulli A, lacono R, Masturzo G, Giglio R, Rossi M, Moracci M. Novel thermophilic hemicellulases for the conversion of lignocellulose for second generation biorefineries. Enzyme Microb Technol. 2015;78:63-73.

24. Youngman P, Perkins JB, Losick R. A novel method for the rapid cloning in Escherichia coli of Bacillus subtilis chromosomal DNA adjacent to Tn917. Mol Gen Genet. 1984;195:424-33.

25. Huang D, Liu J, Qi Y, Yang K, Xu Y, Feng L. Synergistic hydrolysis of xylan using novel xylanases, $\beta$-xylosidases, and an $\alpha$-L-arabinofuranosidase from Geobacillus thermodenitrificans NG80-2. Appl Microbiol Biotechnol. 2017:101:6023-37.

26. Cutting S, Vander Horn PB. Genetic analysis. In: Harwood C, Cutting S, editors. Molecular biological methods for Bacillus. Wiley: Chichester; 1990. p. $27-74$

27. Shi H, Li X, Gu H, Zhang Y, Huang Y, Wang L, Wang F. Biochemical properties of a novel thermostable and highly xylose-tolerant $\beta$-xylosidase/aarabinosidase from Thermotoga thermarum. Biotechnol Biofuels. 2013;6(1):27.

28. Nelson N. A photometric adaptation of the Somogyi method for the determination of glucose. J Biol Chem. 1944;153:375-80.

29. Somogyi M. Notes on sugar determination. J Biol Chem. 1952;195:19-23. 